\title{
Blood Transfusion Has An Adverse Impact On The Prognosis of Patients Receiving Chemotherapy For Advanced Colorectal Cancer: Experience From a Single Institution With a Patient Blood Management Program
}

\author{
Ah Reum Lim \\ Korea University Anam Hospital \\ Jwa Hoon Kim \\ Korea University Anam Hospital \\ Myung Han Hyun \\ Korea University Anam Hospital \\ Won-Jin Chang \\ Korea University Anam Hospital \\ Soohyeon Lee \\ Korea University Anam Hospital \\ Yeul Hong Kim \\ Korea University Anam Hospital \\ Kyong Hwa Park ( $\sim$ khpark@korea.ac.kr) \\ Korea University Anam Hospital https://orcid.org/0000-0002-2464-7920 \\ Jong Hoon Park \\ Korea University Anam Hospital
}

\section{Research Article}

Keywords: cancer-related anemia, minimized blood transfusion, patient blood management, advanced colorectal cancer

Posted Date: January 3rd, 2022

DOI: https://doi.org/10.21203/rs.3.rs-1110008/v1

License: (c) (1) This work is licensed under a Creative Commons Attribution 4.0 International License.

Read Full License 
Version of Record: A version of this preprint was published at Supportive Care in Cancer on March 11th, 2022. See the published version at https://doi.org/10.1007/s00520-022-06949-z. 


\section{Abstract}

Purpose: Perioperative blood transfusion in early stage cancer patients had a negative effect on the prognosis of patients, but the prognostic impact of transfusion in advanced cancer patients remains unclear. To minimize transfusion, a institutional patient blood management (PBM) program was launched, and we evaluated the new program has changed practice and impacted on prognosis of advanced cancer patients.

Methods: We investigated the medical records of colorectal cancer patients who received chemotherapy from 2015 to 2020. The amount and frequency of transfusion, iron replacement and laboratory findings, and overall survival were compared before and after implementation of PBM.

Results: The rate of transfusion in colorectal cancer patients was significantly decreased from 23.5/100 person-quarter in 2015 to 1.2/100 person-quarter in 2020, but iron supplementation therapy was frequently used and the proportion of patients who received transfusion under haemoglobin $7 \mathrm{~g} / \mathrm{dL}$ significantly increased from $15.9 \%$ in 2015 to $55.3 \%$ in 2020 . Multivariate analysis revealed that transfusion was a significant risk factor affecting the overall survival of patients (HR 2.70, 95\% Cl: $1.93-$ $3.78, p<0.001)$. Kaplan-Meier analysis revealed that overall survival was significantly longer in nontransfused patients than in transfused patients (11.0 versus 22.4 months; $\mathrm{HR} 0.69,95 \% \mathrm{Cl}$ : $0.56-0.86$, $p<0.001)$.

Conclusions: This study shows that minimized transfusion through an institutional PBM can positively affect the prognosis of patients who are receiving chemotherapy for advanced colorectal cancer.

\section{Introduction}

The Anemia is a common problem in patients with cancer, particularly among those receiving cytotoxic chemotherapy. The prevalence of anemia in patients with cancer varies according to clinical factors, including the type of malignancy, stage, duration of disease, and chemotherapy regimen. The prevalence of anemia in cancer patients ranges from 30-90\% [1], and one study reported that approximately $40 \%$ of cancer patients are already anaemic prior to treatment [2]. The aetiology of cancer-related anemia is multifactorial, including gastrointestinal bleeding, iron deficiency, malnutrition, metastatic bone marrow infiltration, and chemotherapy-induced myelosuppression [3, 4]. Patients receiving chemotherapy frequently report fatigue, nausea, loss of appetite, and dyspnoea, but these symptoms of anemia are often mistaken for cancer-related symptoms. Uncorrected anemia has a significant impact on the patient's physical, functional and emotional well-being $[5,6]$ and results in decreased adherence to treatment. Therefore, it is important to proactively correct anemia in patients receiving chemotherapy to achieve an optimal clinical outcome.

Current guidelines recommend the active correction of anemia in cancer patients by erythropoiesisstimulating agents (ESA) and iron supplementation [7, 8]. Red blood cell (RBC) transfusion is reserved for patients who are hypovolemic from acute blood loss and refractory with adequate fluid resuscitation or 
patients with chronic anemia unresponsive to iron supplementation. However, blood transfusion has been used to correct anemia for patients with advanced stage cancer in Korea. Considering the recent evidence suggesting the adverse effects of blood transfusion on the prognosis of early stage cancer patients [912], rational application of blood transfusion in advanced cancer patients should be explored.

The implementation of the patient blood management (PBM) program was suggested by World Health Organization in 2010 to reduce RBC transfusion and maintain the quality and safety of transfusions [13]. The PBM program has been standardized as routine practice in the United States and most European countries [14, 15], as well as in a few Asian countries [16]. The Korea University Anam Hospital launched an institutional PBM program in early 2018 [17]. In line with the institutional program, management guidelines for anemia in cancer patients were established and shared with young doctors in the educational programs [17]. As the PBM program became more widely implemented throughout the hospital's system, it was expected that there would be reductions in blood transfusion and practice in cancer care has also been changed. In this study, we examined the impact of the implementation of PBM in cancer care on the patterns of anemia management in the real world setting and evaluated if it affects the prognosis of patients who are receiving chemotherapy for advanced cancer.

\section{Materials And Methods}

\section{Patients}

We conducted a retrospective study by the review of medical records of colorectal cancer patients who received chemotherapy at the cancer centre of the Korea University Anam Hospital from January 2015 to December 2020. Patients were eligible if they were treated with at least one regimen of standard chemotherapy backbone: either leucovorin, fluorouracil, and irinotecan hydrochloride (FOLFIRI) or leucovorin, fluorouracil, and oxaliplatin (mFOLFOX6). Agents (cetuximab or bevacizumab) that target the epidermal growth factor receptor (EGFR) or vascular endothelial growth factor (VEGF) were combined with chemotherapy according to the patient's KRAS mutation status.

\section{Data collection}

Demographic and disease characteristics such as age at diagnosis, gender, primary tumour location (ascending colon, descending colon, or rectum), metastatic sites at diagnosis, number of total chemotherapy regimens, tumour histology (adenocarcinoma, mucinous adenocarcinoma, signet ring cell carcinoma, adenosquamous carcinoma, squamous cell carcinoma), molecular biomarkers (KRAS, NRAS, $B R A F$ mutation), the status of microsatellite instability (MSI), and survival status were collected from electronic health records.

To identify the changes in pattern of anemia management over time, records for the amount and frequency of blood transfusion, iron replacement therapy, and relevant laboratory findings were collected. The data were summarized by quarter-year from the first quarter of 2015 to the fourth quarter of 2020. The rate of RBC transfusion over time was assessed by the percentage of patients transfused. The total 
amount of transfused RBC was assessed by the number of units transfused per patient during hospital admission. Our analytic unit was per 100 person-quarter. Pre-transfusion $\mathrm{Hb}$ value was obtained as the latest $\mathrm{Hb}$ recorded on the database before the transfusion time. The proportion of transfused patients stratified by the pre-transfusion $\mathrm{Hb}$ value was calculated to examine the proportion of patients who received blood transfusions under $\mathrm{Hb} 7.0 \mathrm{~g} / \mathrm{dL}$, the institutional indication for transfusion. Also, in our study cohort, the pre-transfusion $\mathrm{Hb}$ value $>9.0 \mathrm{~g} / \mathrm{dL}$ was considered as an over-transfusion, except in special clinical condition such as acute blood loss.

The overall incidence of anemia at the time of diagnosis was calculated in the study population. To investigate changes in the prescription of iron replacement for anemia management, the proportion of patients receiving oral or intravenous iron supplement therapy was evaluated. We calculated the mean $\mathrm{Hb}$ level for each quarter-year for the entire cohort.

Overall survival (OS) was assessed from date of diagnosis of metastatic cancer to death from any cause or censoring.

\section{Anemia definition}

In this study, anemia was defined according to the WHO classification of anemia. Anemia is defined as a $\mathrm{Hb}$ level of $<12 \mathrm{~g} / \mathrm{dL}$ in women and $<13 \mathrm{~g} / \mathrm{dL}$ in men.

\section{Statistical analysis}

All statistical analyses were conducted using SPSS version 20.0 (Statistical Package for the Social Sciences for Windows software, Chicago, IL, USA). Descriptive statistics are presented as the mean, standard deviation for numerical variables, and as number and percentage for categorical variables. Numerical variables between two independent groups were analysed with student t-test in case of normal distribution and with Mann-Whitney $\mathrm{U}$ test otherwise. The comparison of the rates between the groups was performed by chi square analysis. Survival analyses were performed with Kaplan-Meier analysis. We used Cox regression to identify determinant factors that were associated survival. Backward stepwise model was used with parameters with a p-value below 0.050 . An overall $5 \%$ alpha error level was used to infer statistical significance.

\section{Results}

\section{Patient characteristics}

The demographic and clinical characteristics of the colorectal cancer patients are presented in Table 1. A total of 871 colorectal cancer patients were treated at the Division of Medical Oncology from January 2015 to December 2020. The number of colorectal cancer patients increased over time. The distribution of characteristics such as age, gender, primary tumour location, pathology, and molecular biomarkers were similar before and after the implementation of PBM in 2019. 
Table 1

Patient characteristics before and after implementation of the PBM program

\begin{tabular}{|c|c|c|c|c|}
\hline & $\begin{array}{l}\text { Total } \\
(\mathrm{n}=\mathbf{8 7 1})\end{array}$ & $\begin{array}{l}\text { Pre-PBM* } \\
(n=509)\end{array}$ & $\begin{array}{l}\text { Post-PBM } \\
(\mathrm{n}=362)\end{array}$ & p-value \\
\hline Age, years (range) & $61.9(23-89)$ & $62.1(23-89)$ & $61.5(25-87)$ & 0.412 \\
\hline Gender, n (\%) & & & & 0.268 \\
\hline Male & $554(63.6)$ & $316(62.1)$ & $238(65.7)$ & \\
\hline Female & $317(36.4)$ & $193(37.9)$ & $124(34.3)$ & \\
\hline Primary location, n (\%) & & & & 0.723 \\
\hline Ascending colon & $194(22.2)$ & $112(22.0)$ & $82(22.7)$ & \\
\hline Descending colon & $268(30.8)$ & $162(31.8)$ & $106(29.3)$ & \\
\hline Rectum & $409(47.0)$ & $235(46.2)$ & $174(48.1)$ & \\
\hline Metastatic site, n (\%) & & & & 0.612 \\
\hline 0 & $181(20.8)$ & $98(19.3)$ & $83(22.9)$ & \\
\hline 1 & $316(36.3)$ & $187(36.7)$ & $129(35.6)$ & \\
\hline 2 & $232(26.6)$ & $138(27.1)$ & $94(26.0)$ & \\
\hline More than 2 & $142(16.3)$ & $86(16.9)$ & $56(15.5)$ & \\
\hline $\begin{array}{l}\text { Number of total chemotherapy } \\
\text { regimens in a lifetime, } \mathrm{n}(\%)\end{array}$ & & & & $<0.001$ \\
\hline 1 & $478(54.9)$ & $221(43.4)$ & $257(71.0)$ & \\
\hline 2 & $219(25.1)$ & $135(26.5)$ & $84(23.2)$ & \\
\hline More than 2 & $174(20.0)$ & $153(30.1)$ & $21(5.8)$ & \\
\hline Pathology, n (\%) & & & & 0.242 \\
\hline Adenocarcinoma & $800(91.8)$ & $472(92.7)$ & $328(90.6)$ & \\
\hline Mucinous adenocarcinoma & $60(6.9)$ & $31(6.1)$ & $29(8.0)$ & \\
\hline Others** & $11(1.2)$ & $6(1.2)$ & $5(1.4)$ & \\
\hline \multicolumn{5}{|c|}{ PBM, Patient blood management; MSI, Microsatellite instability. } \\
\hline \multicolumn{5}{|c|}{ * Analyzed patients before (pre-PBM) and after (post-PBM) the implementation of PBM. } \\
\hline \multicolumn{5}{|c|}{ ** These include signet ring cell carcinoma, adenosquamous carcinoma, squamous cell carcinoma. } \\
\hline *** Data not from all patients & & & & \\
\hline
\end{tabular}




\begin{tabular}{|c|c|c|c|c|}
\hline & $\begin{array}{l}\text { Total } \\
(\mathrm{n}=\mathbf{8 7 1})\end{array}$ & $\begin{array}{l}\text { Pre-PBM* } \\
(n=509)\end{array}$ & $\begin{array}{l}\text { Post-PBM } \\
(\mathrm{n}=362)\end{array}$ & p-value \\
\hline \multicolumn{5}{|c|}{ 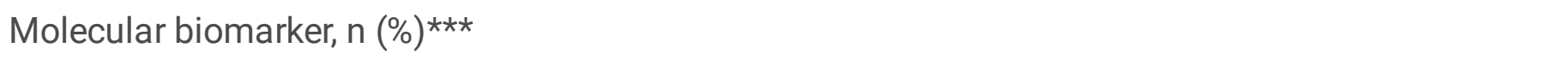 } \\
\hline KRAS mutation & $378(43.4)$ & $225(44.2)$ & $153(47.2)$ & 0.099 \\
\hline NRAS mutation & $19(2.2)$ & $12(2.4)$ & $7(1.9)$ & $<0.001$ \\
\hline$B R A F$ mutation & $32(3.6)$ & $18(3.5)$ & $14(3.9)$ & $<0.001$ \\
\hline MSI high & $17(2.0)$ & $12(2.4)$ & $5(1.4)$ & 0.203 \\
\hline \multicolumn{5}{|c|}{ PBM, Patient blood management; MSI, Microsatellite instability. } \\
\hline \multicolumn{5}{|c|}{ * Analyzed patients before (pre-PBM) and after (post-PBM) the implementation of PBM. } \\
\hline \multicolumn{5}{|c|}{ ** These include signet ring cell carcinoma, adenosquamous carcinoma, squamous cell carcinoma. } \\
\hline
\end{tabular}

Among the 871 patients, 554 (63.6\%) were male and 317 (36.4\%) were female. The median age was 61.9 years (range, 23-89). The main anatomical sites of the primary tumour at diagnosis were as follows: rectum (47.0\%), descending colon (30.8\%), and ascending colon (22.2\%). At the time of diagnosis, the most common histologic type was adenocarcinoma (92.5\%) and the number of metastatic sites varied (20.8\% none, $36.3 \% 1$ site, $26.6 \% 2$ sites, and $16.3 \%$ more than 2 sites). With the increase use of precision medicine, the detection rate of mutational status of biomarkers increased accordingly.

\section{RBC transfusion rates}

The rate of RBC transfusion significantly decreased in the study population over time, from 23.5/100 person-quarter in the 4 th quarter of 2015 to 1.2/100 person-quarter in the 4th quarter of 2020 (Fig. 1). The total amount of transfused RBC decreased from 100.0 units/100 person-quarter in the 4th quarter of 2015 to 3.7 units/100 person-quarter in the 4 th quarter of 2020 . Hb levels before transfusion were evaluated among the patients who were transfused. The proportion of patients who received blood transfusions under $7 \mathrm{~g} / \mathrm{dL}$, the institutional indication for transfusion, significantly increased yearly during the study period: $15.9 \%, 23.7 \%, 28.7 \%, 32.3 \%, 52.2 \%$ and $55.3 \%$ for the study periods. Conversely, the proportion of patients receiving RBC transfusion at $\mathrm{Hb} \geq 9 \mathrm{~g} / \mathrm{dL}$ significantly decreased yearly over the study period: $12.3 \%, 5.3 \%, 2.0 \%, 5.2 \%, 2.2 \%$, and $0 \%$ (Fig. 2).

\section{Pattern of anemia treatment}

The overall incidence of anemia at the time of diagnosis was $67.3 \%$ in the study population. The proportion of patients receiving iron supplementation therapy significantly increased after implementation of PBM: from $0.4 \%$ in 2015 to $20.8 \%$ in 2020. Oral iron supplements were more commonly prescribed and steadily increased, from 4.0/100 person-year in 2015 to 13.1/100 person-year in 2020. Use of intravenous iron also increased over several years (Fig. 3). 


\section{Hemoglobin data by quarter-year}

During the study period, the mean hemoglobin level of the patients was $11.2 \pm 2.1 \mathrm{~g} / \mathrm{dL}$ in the $1 \mathrm{st}$ quarter of 2015 and this value significantly increased to $11.9 \pm 1.6 \mathrm{~g} / \mathrm{dL}$ in the 4th quarter of 2020 (Supplement Fig. 1).

\section{Overall survival based on transfusion}

During the entire study period, 20.2\% (176/871) of patients received at least one unit of RBC transfusion. The prognostic impact of transfusion on OS was evaluated at the median follow-up of 34.1 months (range, 3.0 to 169.7 months).

Univariate analysis for OS revealed that age ( $\geq 61.9$ years), number of distant metastatic sites, presence of biomarkers (KRAS mutation, MSI), and history of transfusion were the unfavourable predictors for OS. In multivariate analysis, history of transfusion during chemotherapy was a significant risk factor for decreased OS (hazard ratio $(H R)=2.696,95 \%$ confidence interval $[C l], 1.925$ to $3.776, P<0.001$ ) after number of distant metastatic sites $>1(H R=4.616)$ (Table 2). Kaplan-Meier analysis estimated that the median OS among patients who received transfusion was 22.4 months $(95 \% \mathrm{Cl}, 16.6$ to 34.0$)$ compared with 11.0 months ( $95 \% \mathrm{Cl}, 8.3$ to 14.3) among patients who did not receive transfusion (HR for death, $0.69 ; 96.4 \% \mathrm{Cl}, 0.56$ to $0.86 ; \mathrm{p}<0.001$ ) (Fig. 4). 
Table 2

Univariate and multivariate analysis for overall survival

\begin{tabular}{|c|c|c|c|c|c|c|}
\hline \multirow[t]{2}{*}{ Factor } & \multicolumn{3}{|c|}{ Univariate analysis } & \multicolumn{3}{|c|}{ Multivariate analysis } \\
\hline & $\mathrm{HR}$ & $95 \% \mathrm{Cl}$ & $\begin{array}{l}\mathrm{p}- \\
\text { value }\end{array}$ & $\mathrm{HR}$ & $95 \% \mathrm{Cl}$ & $\begin{array}{l}\mathrm{p}- \\
\text { value }\end{array}$ \\
\hline Age $(\geq 61.9 \text { vs. }<61.9)^{\star}$ & 1.03 & $\begin{array}{l}1.01- \\
1.04\end{array}$ & 0.001 & 1.03 & $\begin{array}{l}1.02- \\
1.05\end{array}$ & $<0.001$ \\
\hline Gender (Female vs. Male) & 0.73 & $\begin{array}{l}0.52- \\
1.01\end{array}$ & 0.059 & & & \\
\hline \multicolumn{7}{|l|}{ Primary location } \\
\hline Ascending colon & & & 0.158 & & & \\
\hline Descending colon & 0.93 & $\begin{array}{l}0.60- \\
1.42\end{array}$ & 0.726 & & & \\
\hline Rectum & 0.69 & $\begin{array}{l}0.45- \\
1.06\end{array}$ & 0.088 & & & \\
\hline \multicolumn{7}{|l|}{ Metastatic site } \\
\hline 0 & & & $<0.001$ & & & $<0.001$ \\
\hline 1 & 5.40 & $\begin{array}{l}2.13- \\
13.68\end{array}$ & $<0.001$ & 4.62 & $\begin{array}{l}1.81- \\
11.75\end{array}$ & 0.001 \\
\hline 2 & 11.23 & $\begin{array}{l}4.46- \\
28.3\end{array}$ & $<0.001$ & 9.94 & $\begin{array}{l}3.93- \\
25.13\end{array}$ & $<0.001$ \\
\hline More than 2 & 18.46 & $\begin{array}{l}7.34- \\
46.46\end{array}$ & $<0.001$ & 14.33 & $\begin{array}{l}5.63- \\
36.48\end{array}$ & $<0.001$ \\
\hline \multicolumn{7}{|c|}{ Total Chemotherapy regimens } \\
\hline 1 & & & $<0.001$ & & & 0.486 \\
\hline 2 & 1.67 & $\begin{array}{l}1.04- \\
2.67\end{array}$ & 0.033 & 0.74 & $\begin{array}{l}0.45- \\
1.23\end{array}$ & 0.245 \\
\hline More than 2 & 2.80 & $\begin{array}{l}1.87- \\
4.20\end{array}$ & $<0.001$ & 0.89 & $\begin{array}{l}0.54- \\
1.46\end{array}$ & 0.638 \\
\hline \multicolumn{7}{|l|}{ Pathology } \\
\hline Adenocarcinoma & & & 0.714 & & & \\
\hline
\end{tabular}

PBM, Patient blood management; MSI, Microsatellite instability.

* 61.9 years is median age.

** These include signet ring cell carcinoma, adenosquamous carcinoma, squamous cell carcinoma.

*** Data not from all patients available 


\begin{tabular}{|c|c|c|c|c|c|c|}
\hline \multirow{2}{*}{$\begin{array}{l}\text { Factor } \\
\text { Mucinous adenocarcinoma }\end{array}$} & \multicolumn{3}{|c|}{ Univariate analysis } & \multicolumn{3}{|c|}{ Multivariate analysis } \\
\hline & 0.57 & $\begin{array}{l}0.27- \\
1.22\end{array}$ & 0.146 & & & \\
\hline Others $\star \star$ & 0.00 & & 0.963 & & & \\
\hline \multicolumn{7}{|l|}{ 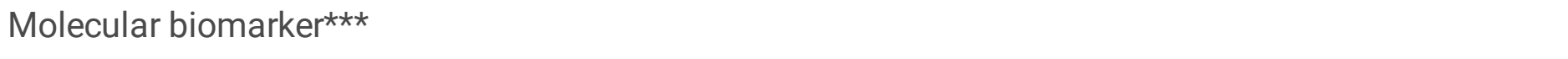 } \\
\hline KRAS mutation & 0.97 & $\begin{array}{l}0.70- \\
1.36\end{array}$ & 0.032 & 0.85 & $\begin{array}{l}0.60- \\
1.18\end{array}$ & 0.372 \\
\hline NRAS mutation & 0.94 & $\begin{array}{l}0.61- \\
1.45\end{array}$ & 0.79 & & & \\
\hline$B R A F$ mutation & 0.92 & $\begin{array}{l}0.68- \\
1.25\end{array}$ & 0.109 & & & \\
\hline \multicolumn{7}{|l|}{ MSI status } \\
\hline Stable & & & 0.013 & & & 0.540 \\
\hline Low & 1.96 & $\begin{array}{l}1.12- \\
3.43\end{array}$ & 0.019 & 0.66 & $\begin{array}{l}0.09- \\
4.86\end{array}$ & 0.685 \\
\hline High & 1.20 & $\begin{array}{l}0.68- \\
2.11\end{array}$ & 0.528 & 1.01 & $\begin{array}{l}0.43- \\
2.35\end{array}$ & 0.986 \\
\hline $\begin{array}{l}\text { PBM } \\
\text { (Post-PBM vs. Pre-PBM) }\end{array}$ & 0.91 & $\begin{array}{l}0.58- \\
1.40\end{array}$ & 0.628 & & & \\
\hline $\begin{array}{l}\text { Transfusion status (Transfused vs. } \\
\text { Nontransfused) }\end{array}$ & 3.61 & $\begin{array}{l}2.60- \\
5.01\end{array}$ & $<0.001$ & 2.70 & $\begin{array}{l}1.93- \\
3.78\end{array}$ & $<0.001$ \\
\hline \multicolumn{7}{|c|}{ PBM, Patient blood management; MSI, Microsatellite instability. } \\
\hline \multicolumn{7}{|l|}{ * 61.9 years is median age. } \\
\hline \multicolumn{7}{|c|}{ 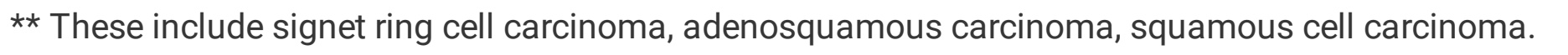 } \\
\hline$\star \star \star$ Data not from all patients availal & & & & & & \\
\hline
\end{tabular}

\section{Discussion}

Correction of anemia in patients who are receiving systemic chemotherapy has important clinical value, as anemia negatively impacts the patient's quality of life and compliance of treatment in the oncology clinic. In this retrospective study, we showed that the pattern of anemia management in colorectal cancer patients receiving chemotherapy was significantly changed after implementation of the PBM program in oncology practice. The number of patients receiving RBC transfusion as well as the amount of transfused RBC decreased after the specific guideline for cancer patients was implemented. Instead, iron supplementation was significantly increased to minimize blood transfusions. As a result, the mean hemoglobin levels increased gradually over the study period, while the baseline clinical characteristics of 
patients remained consistent. Of note, we also observed that blood transfusion was a significant unfavourable factor influencing OS along with the number of metastatic sites at diagnosis in advanced colorectal cancer patients.

In patients with anemia receiving myelosuppressive chemotherapy for advanced cancer, it is recommended to correct anemia with iron replacement and/or ESA to reduce transfusion $[7,8]$. However, blood transfusion has also been frequently used in clinical practice alone or in combination with pharmaceutical measures. Many studies showed that perioperative blood transfusion in early stage cancer patients had a negative effect both on short-term surgical outcome and long-term prognosis of patients [18-21]. Most of all, colon cancer was the prototype of disease that was proven the relevance of transfusion and clinical outcome [22,23]. The negative impact of blood transfusion was documented in multiple cancer types after extended follow-up investigations [24, 25], supporting restrictive transfusion in early stage cancer patients. However, the prognostic impact of transfusion in advanced cancer patients had not been sufficiently investigated. Patients with malignancy in the gastrointestinal tract are more likely to have anemia at the time of cancer diagnosis because of chronic blood loss, insufficient food intake, or chronic inflammatory condition. Moreover, anemia is aggravated with repeated cycles of chemotherapy. In the oncology clinic, however, correction of anemia is not a priority issue compared with the choice of treatment, management of side effects from chemotherapy, and pain control. In this study, patients who were transfused using packed RBC showed an inferior survival time irrespective of chemotherapy or initial tumour burden.

In the current analysis, blood transfusion was required in $20 \%$ of the patients (175 out of 871 ). Patients who required at least one unit of transfusion were characterized by more metastatic sites at diagnosis (more than 2 sites, 53 of 175 [30.3\%] vs. 89 of 696 [12.8\%]; $p<0.001$ ) and more chemotherapy regimens over the lifetime (more than 2 courses, 75 of 175 [42.8\%] vs. 99 of 696 [14.2\%]; $p<0.001$ ) (Supplementary Table 1). The increased probability of transfusion in patients with a high tumour burden could be explained by the fact that advanced cancer induces functional iron deficiency mediated by inflammatory mediators; hepcidin [26-29]. Thus, standard oral iron supplementation or ESA might not be effective for this patient group as in patients with benign conditions. Nevertheless, considering the limited therapeutic options for advanced colorectal cancer patients, better supportive care like restricting transfusion for anemia correction might be a valuable strategy to improve clinical outcome.

There are several well-known adverse events from blood transfusion, including blood-born infections, hemolytic reactions, transfusion-related acute lung injury (TRALI), and transfusion-related immunomodulation (TRIM) [30]. TRIM is one of the major mechanisms underlying the negative impact of blood transfusion on clinical outcome in cancer patients. TRIM is mediated by residual leukocytes, apoptotic cells, and microparticles in blood components. Upon transfusion, the components of transfusion can modify immune functions, including decreasing the number of lymphocytes, CD4 cells, the CD4/CD8 T-cell ratio, NK cells and the lymphocyte response to mitogens. These effects might contribute to cancer growth and dissemination by compromising immune surveillance [31, 32]. The prognostic impact on patients receiving immune checkpoint inhibitors is not known. Indeed, there is 
sufficient clinical evidence to support the practice of restrictive transfusion and proactive correction of anemia in both early and advanced stage cancer patients.

Implementation of PBM at the institutional level is usually challenging, especially for high volume clinical settings like oncology clinics. The recognition of the potential hazards of blood transfusion and change in practice by young doctors who are responsible for primary care takes time. Good availability and low cost of transfusion were additional hurdles in building up the new culture in Korea. With institutional level educational programs and continuous feedback to faculty physicians, the use of blood transfusion dramatically decreased and the mean hemoglobin level in patients significantly increased in a short period. Moreover, the increased awareness of anemia by the treatment team was reflected by the increase in iron replacement. For the continuity of care pattern in anemia, cancer patient-specific guidelines were established and shared with rotating residents. Encouraged by the results from this study, a new practice of attentive care of anemia with restrictive transfusion is now the standard of care for all cancer types in our institution.

There are several limitations in our study. First, this is a retrospective study, and thus the prognosis of the patients might be inherently affected by unrecognized confounding variables. In oncology patients, the prognosis of patients is usually improved with the implementation of new agents and better supportive care. To investigate the prognostic impact of anemia correction, we selected metastatic colorectal cancer, as the standard of care has not significantly changed over recent years. Second, the results presented here are based on a single cancer type from a single institutional experience. Thus, the value of restrictive transfusion should be further evaluated in other cancer types and the clinical context in a multicentre or national database setting. Despite these limitations, we demonstrated that the implementation of restrictive transfusion by the implementation of PBM program were feasible to change practice patterns. Through these changes, we observed many valuable benefits in the oncology clinic, not only saving the costs of blood transfusion and reducing the burden of time-consuming and high-risk medical practice of caregivers, but also improving patient prognosis.

In conclusion, allogenic blood transfusion is an independent adverse prognostic factor in patients receiving chemotherapy for advanced colorectal cancer. Increased awareness of anemia and proactive use of medicinal strategies should be considered rather than transfusion for better prognosis of these patients.

\section{Declarations}

Acknowledgments: None

Funding: This research received no external funding.

Conflicts of Interest: The authors declare no conflict of interest.

Data Availability: The data presented in this study are available on request from the author. 
Code availability: Not applicable.

Author Contributions: Conceptualization: A.R.L., K.H.P. and J.H.P.; methodology, J.H.K. and K.H.P.; data acquisition and interpretation: A.R.L., M.H.H., W.-J.C., S.L., Y.H.K. and K.H.P.; formal analysis: A.R.L., K.H.P. and J.H.P.; data curation: A.R.L., writing-original draft preparation: A.R.L., K.H.P. and J.H.P.; writingreview and editing: A.R.L., K.H.P. and J.H.P.; supervision: K.H.P. All authors have read and agreed to the published version of the manuscript.

Institutional Review Board Statement: The study was conducted according to the guidelines of the Declaration of Helsinki, and approved by the Institutional Review Board of the Korea University Anam Hospital (IRB number: 2021AN0457, date of acceptance 16 September 2021).

Consent to paticipate: Informed consent was waived because of the retrospective nature of the study and there were minimal risks to subjects.

Consent for publication: Not applicable.

\section{References}

1. Knight K, Wade S, Balducci L (2004) Prevalence and outcomes of anemia in cancer: a systematic review of the literature. Am J Med. https://doi.org/10.1016/j.amjmed.2003.12.008. 116 Suppl 7A:11S-26S

2. Ludwig H, Van Belle S, Barrett-Lee P et al (2004) The European Cancer Anaemia Survey (ECAS): a large, multinational, prospective survey defining the prevalence, incidence, and treatment of anaemia in cancer patients. Eur J Cancer 40:2293-2306. https://doi.org/10.1016/j.ejca.2004.06.019

3. Birgegård G, Aapro MS, Bokemeyer C et al (2005) Cancer-related anemia: pathogenesis, prevalence and treatment. Oncology 68(Suppl 1):3-11. https://doi.org/10.1159/000083128

4. Busti F, Marchi G, Ugolini S, Castagna A, Girelli D (2018) Anemia and Iron Deficiency in Cancer Patients: Role of Iron Replacement Therapy. Pharmaceuticals (Basel) 11:94. https://doi.org/10.3390/ph11040094

5. Cella D (1998) Factors influencing quality of life in cancer patients: anemia and fatigue. Semin Oncol 25(3 Suppl 7):43-46

6. Cella D, Kallich J, McDermott A, Xu X (2004) The longitudinal relationship of hemoglobin, fatigue and quality of life in anemic cancer patients: results from five randomized clinical trials. Ann Oncol 15:979-986. https://doi.org/10.1093/annonc/mdh235

7. Aapro M, Beguin Y, Bokemeyer $C$ et al (2018) Management of anaemia and iron deficiency in patients with cancer: ESMO Clinical Practice Guidelines. Ann Oncol 29:iv96-110. https://doi.org/10.1093/annonc/mdx758

8. Bohlius J, Bohlke K, Castelli R et al (2019) Management of cancer-associated anemia with erythropoiesis-stimulating agents: ASCO/ASH clinical practice guideline update. Blood Adv 3:1197- 
1210. https://doi.org/10.1182/bloodadvances.2018030387

9. Clarke H, Pallister CJ (2005) The impact of anaemia on outcome in cancer. Clin Lab Haematol 27:113. https://doi.org/10.1111/j.1365-2257.2004.00664.x

10. Harper P, Littlewood T (2005) Anaemia of cancer: impact on patient fatigue and long-term outcome. Oncology 69 Suppl 22-7. https://doi.org/10.1159/000088282

11. Ng T, Ryder BA, Chern H, Sellke FW, Machan JT, Harrington DT, Cioffi WG (2012) Leukocyte-depleted blood transfusion is associated with decreased survival in resected early-stage lung cancer. $\mathrm{J}$ Thorac Cardiovasc Surg 143:815-819. https://doi.org/10.1016/j.jtcvs.2011.12.031

12. Tartter PI (1992) The association of perioperative blood transfusion with colorectal cancer recurrence. Ann Surg 216:633-638. https://doi.org/10.1097/00000658-199212000-00004

13. World Health Assembly (2010) Availability, safety and quality of blood products: report by the Secretariat. World Health Organization, Geneva, p A6320

14. Gammon HM, Waters JH, Watt A, Loeb JM, Donini-Lenhoff A (2011) Developing performance measures for patient blood management. Transfusion 51:2500-2509.

https://doi.org/10.1111/j.1537-2995.2011.03406.x

15. Shander A, Van Aken H, Colomina MJ, Gombotz H, Hofmann A, Krauspe R, Lasocki S, Richards T, Slappendel R, Spahn DR (2012) Patient blood management in Europe. Br J Anaesth 109:55-68. https://doi.org/10.1093/bja/aes139

16. Zhang R, Wu Z, Wang Z, Ye S, Li C, Lu L, Wang Y, Rao S (2018) Current status of clinical transfusion practice in Sichuan, China: A cross-sectional survey. Transfus Apher Sci 57:65-70. https://doi.org/10.1016/j.transci.2017.12.001

17. Shin HJ, Kim JH, Park Y, Ahn KH, Jung JS, Park JH (2021) Effect of patient blood management system and feedback programme on appropriateness of transfusion: An experience of Asia's first Bloodless Medicine Center on a hospital basis. Transfus Med 31:55-62. https://doi.org/10.1111/tme.12754

18. Boshier PR, Ziff C, Adam ME, Fehervari M, Markar SR, Hanna GB (2018) Effect of perioperative blood transfusion on the long-term survival of patients undergoing esophagectomy for esophageal cancer: a systematic review and meta-analysis. Dis Esophagus 31. https://doi.org/10.1093/dote/dox134

19. Cata JP, Wang H, Gottumukkala V, Reuben J, Sessler DI (2013) Inflammatory response, immunosuppression, and cancer recurrence after perioperative blood transfusions. $\mathrm{Br} \mathrm{J}$ Anaesth 110:690-701. https://doi.org/10.1093/bja/aet068

20. Pang QY, An R, Liu HL (2019) Perioperative transfusion and the prognosis of colorectal cancer surgery: a systematic review and meta-analysis. World J Surg Oncol 17:1-11. https://doi.org/10.1186/s12957-018-1551-y

21. Parrott NR, Lennard TW, Taylor RM, Proud G, Shenton BK, Johnston ID (1986) Effect of perioperative blood transfusion on recurrence of colorectal cancer. Br J Surg 73:970-973. https://doi.org/10.1002/bjs.1800731208 
22. Busch OR, Hop WC, van Hoynck MA, Marquet RL, Jeekel J (1993) Blood transfusions and prognosis in colorectal cancer. N Engl J Med 328:1372-1376. https://doi.org/10.1056/nejm199305133281902

23. Väyrynen JP, Tuomisto A, Väyrynen SA, Klintrup K, Karhu T, Mäkelä J, Herzig KH, Karttunen TJ, Mäkinen MJ (2018) Preoperative anemia in colorectal cancer: relationships with tumor characteristics, systemic inflammation, and survival. Sci Rep 8:1-11. https://doi.org/10.1038/s41598-018-19572-y

24. Al-Refaie WB, Parsons HM, Markin A, Abrams J, Habermann EB (2012) Blood transfusion and cancer surgery outcomes: a continued reason for concern. Surgery 152:344-354. https://doi.org/10.1016/j.surg.2012.06.008

25. Squires MH 3, Kooby DA, Poultsides GA et al (2015) Effect of Perioperative Transfusion on Recurrence and Survival after Gastric Cancer Resection: A 7-Institution Analysis of 765 Patients from the US Gastric Cancer Collaborative. J Am Coll Surg 221:767-777. https://doi.org/10.1016/j.jamcollsurg.2015.06.012

26. Bregman DB, Morris D, Koch TA, He A, Goodnough LT (2013) Hepcidin levels predict nonresponsiveness to oral iron therapy in patients with iron deficiency anemia. Am J Hematol 88:97-101. https://doi.org/10.1002/ajh.23354

27. Rivera S, Liu L, Nemeth E, Gabayan V, Sorensen OE, Ganz T (2005) Hepcidin excess induces the sequestration of iron and exacerbates tumor-associated anemia. Blood 105:1797-1802. https://doi.org/10.1182/blood-2004-08-3375

28. Roy CN, Andrews NC (2005) Anemia of inflammation: the hepcidin link. Curr Opin Hematol 12:107111. https://doi.org/10.1097/00062752-200503000-00001

29. Weiss G, Goodnough LT (2005) Anemia of chronic disease. N Engl J Med 352:1011-1023. https://doi.org/10.1056/NEJMra041809

30. Aguilar-Nascimento JE, Zampieri-Filho JP, Bordin JO (2021) Implications of perioperative allogeneic red blood cell transfusion on the immune-inflammatory response. Hematol Transfus Cell Ther 43:58-64. https://doi.org/10.1016/j.htct.2020.03.003

31. Buddeberg F, Schimmer BB, Spahn DR (2008) Transfusion-transmissible infections and transfusionrelated immunomodulation. Best Pract Res Clin Anaesthesiol 22:503-517. https://doi.org/10.1016/j.bpa.2008.05.003

32. Goubran H, Sheridan D, Radosevic J, Burnouf T, Seghatchian J (2017) Transfusion-related immunomodulation and cancer. Transfus Apher Sci 56:336-340. https://doi.org/10.1016/j.transci.2017.05.019

\section{Figures}



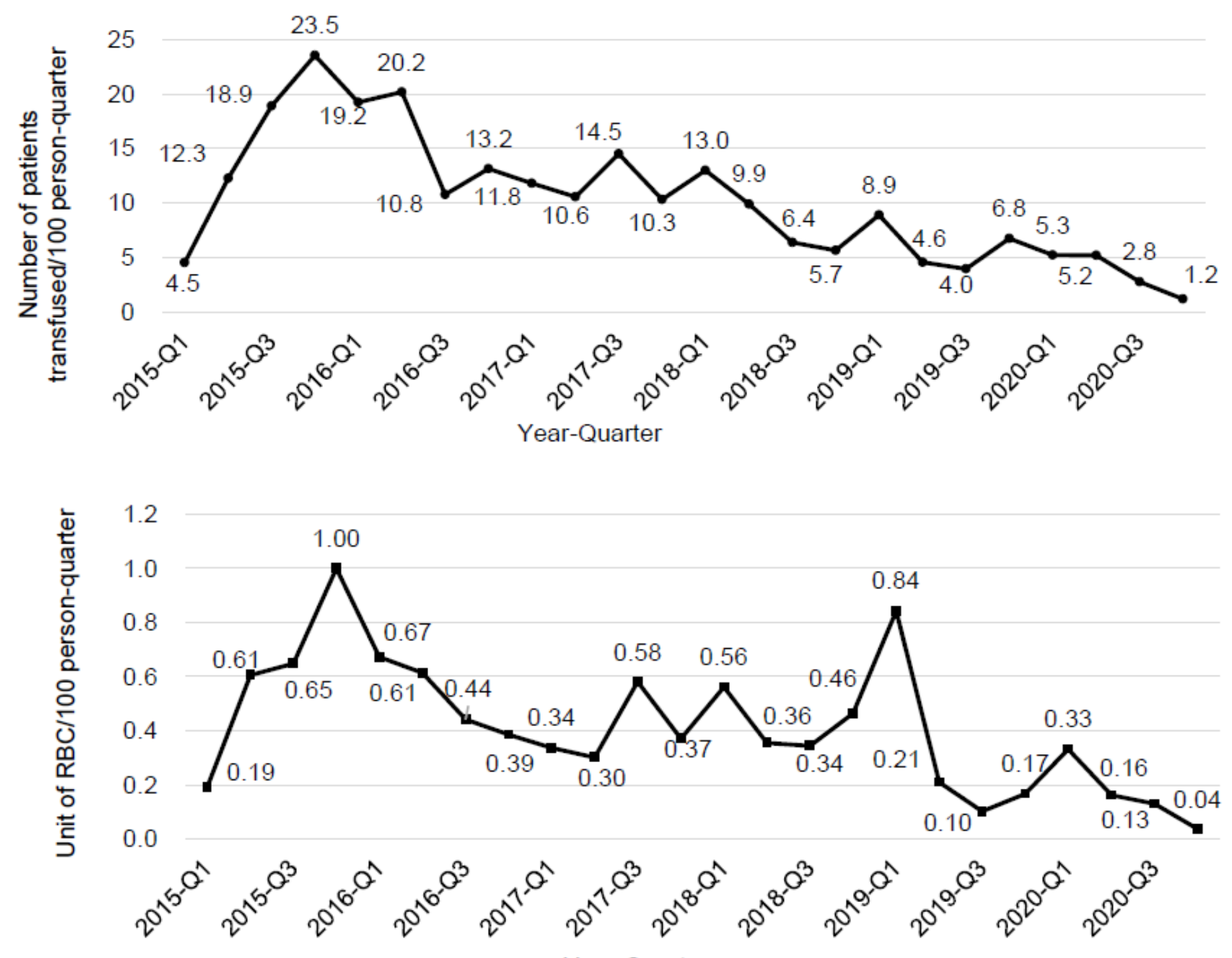

Year-Quarter

Figure 1

RBC Transfusion trend: (a) Number of patients transfused/100 person per year-quarter and (b) total unit of RBC transfusion/100 person per year-quarter from 2015 to 2020 . RBC, red blood cell 


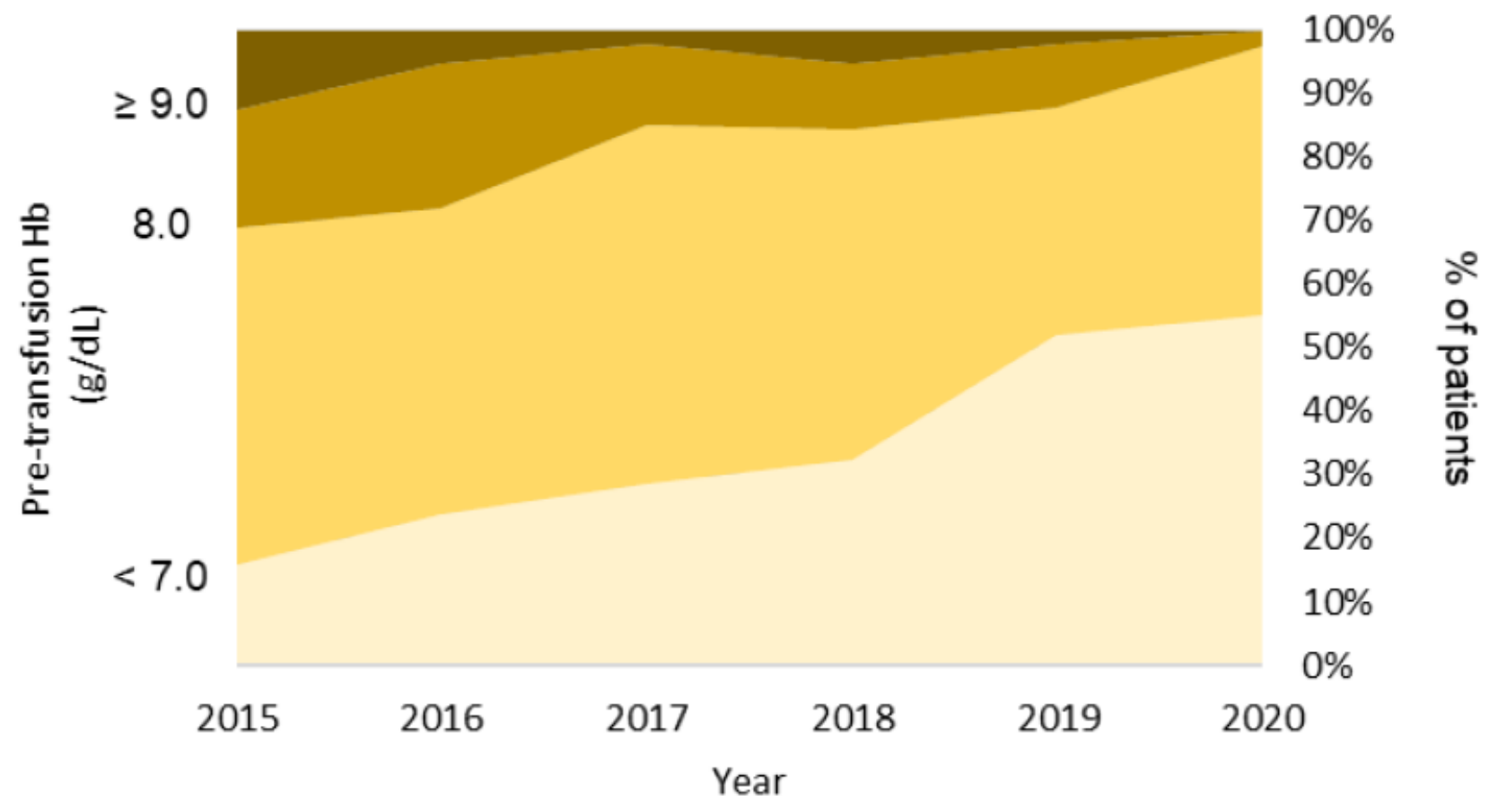

\begin{tabular}{lllllll}
\hline & $\begin{array}{l}2015 \\
(\mathrm{n}=138)\end{array}$ & $\begin{array}{l}2016 \\
(\mathrm{n}=114)\end{array}$ & $\begin{array}{l}2017 \\
(\mathrm{n}=101)\end{array}$ & $\begin{array}{l}2018 \\
(\mathrm{n}=96)\end{array}$ & $\begin{array}{l}2019 \\
(\mathrm{n}=90)\end{array}$ & $\begin{array}{l}2020 \\
(\mathrm{n}=76)\end{array}$ \\
\hline $\mathrm{Hb}<7$ & $22(15.9 \%)$ & $27(23.7 \%)$ & $29(28.7 \%)$ & $31(32.3 \%)$ & $47(52.2 \%)$ & $42(55.3 \%)$ \\
$7 \leq \mathrm{Hb}<8$ & $73(52.9 \%)$ & $55(48.2 \%)$ & $57(56.4 \%)$ & $50(52.1 \%)$ & $32(35.6 \%)$ & $32(42.1 \%)$ \\
$8 \leq \mathrm{Hb}<9$ & $26(18.8 \%)$ & $26(22.8 \%)$ & $13(12.9 \%)$ & $10(10.4 \%)$ & $9(10.0 \%)$ & $2(2.6 \%)$ \\
$\mathrm{Hb} \geq 9$ & $17(12.3 \%)$ & $6(5.3 \%)$ & $2(2.0 \%)$ & $5(5.2 \%)$ & $2(2.2 \%)$ & $0(0.0 \%)$ \\
\hline
\end{tabular}

\section{Figure 2}

Yearly number of patients transfused stratified by pre-transfusion $\mathrm{Hb}$ levels from 2015 to 2020. Pretransfusion $\mathrm{Hb}$ level was obtained as the latest $\mathrm{Hb}$ recorded on the database before the transfusion time. $\mathrm{Hb}$, hemoglobin. 


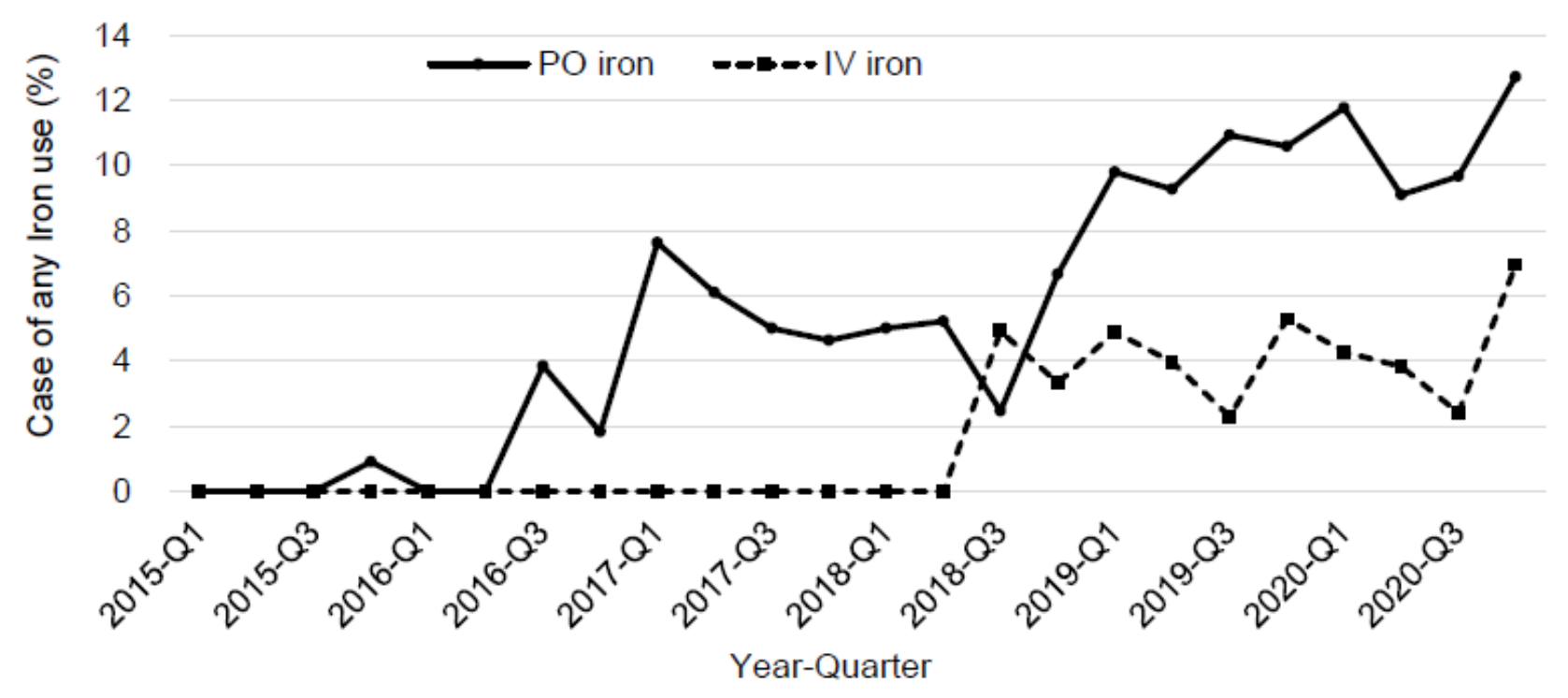

\begin{tabular}{ccccccc}
\hline & $\begin{array}{c}2015 \\
(\mathrm{n}=222)\end{array}$ & $\begin{array}{c}2016 \\
(\mathrm{n}=207)\end{array}$ & $\begin{array}{c}2017 \\
(\mathrm{n}=213)\end{array}$ & $\begin{array}{c}2018 \\
(\mathrm{n}=233)\end{array}$ & $\begin{array}{c}2019 \\
(\mathrm{n}=314)\end{array}$ & $\begin{array}{c}2020 \\
(\mathrm{n}=404)\end{array}$ \\
\hline Incidence of anemia & $78.1 \%$ & $69.1 \%$ & $67.4 \%$ & $61.9 \%$ & $68.0 \%$ & $63.2 \%$ \\
Total iron supplement & $1(0.4 \%)$ & $6(2.9 \%)$ & $13(6.1 \%)$ & $19(8.1 \%)$ & $61(19.4 \%)$ & $84(20.8 \%)$ \\
PO iron & $1(0.4 \%)$ & $6(2.9 \%)$ & $13(6.1 \%)$ & $14(6.0 \%)$ & $39(12.4 \%)$ & $53(13.1 \%)$ \\
IV iron & $0(0.0 \%)$ & $0(0.0 \%)$ & $0(0.0 \%)$ & $5(2.1 \%)$ & $22(7.0 \%)$ & $31(7.7 \%)$ \\
\hline
\end{tabular}

Figure 3

Proportion of use of PO/IV iron replacement therapy by year-quarter from 2015 to 2020: Incidence of anemia [in cluded patients with $\mathrm{Hb}$ levels $<13 \mathrm{~g} / \mathrm{dL}$ (males) or $<12 \mathrm{~g} / \mathrm{dL}$ (females)] and total (PO/IV) iron supplement during study period. PO, per os/orally; IV, intravenous. 


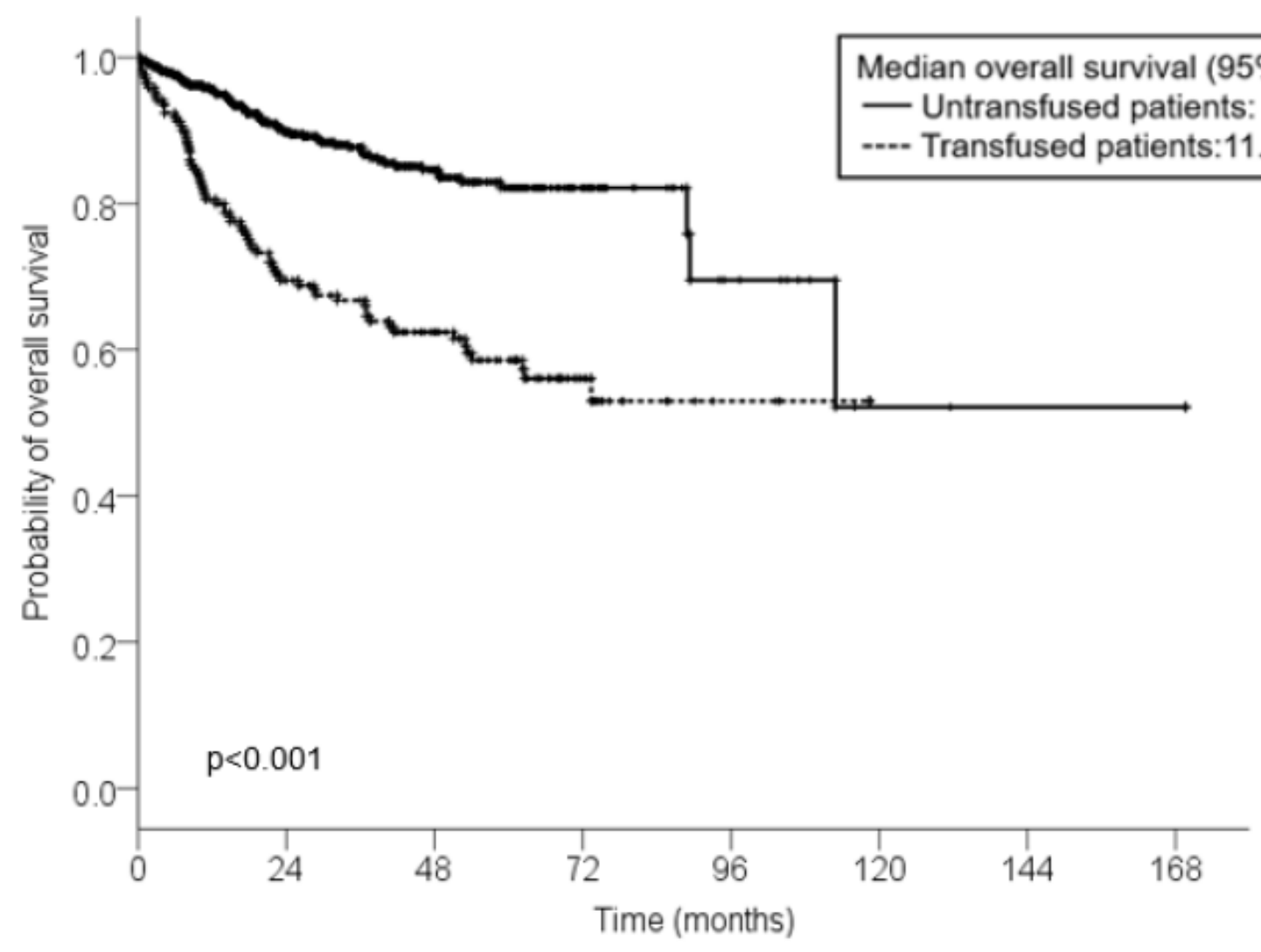

Figure 4

Kaplan-Meier curve for overall survival according to RBC transfusion status. Median overall survival of transfused patients (dashed line) was significantly lower than that of untransfused patients (solid line).

\section{Supplementary Files}

This is a list of supplementary files associated with this preprint. Click to download.

- Supplement.docx 